\title{
Education as a Process and Result
}

\author{
Halima Sofradzija ${ }^{1}$, Sandro Sehic ${ }^{2}$, Abdel Alibegovic ${ }^{3}$, Sarina Bakic ${ }^{4}$, Merima Camo ${ }^{5}$ \\ ${ }^{1}$ Faculty of Political Science, University of Sarajevo, Skenderija 72, 71000 Sarajevo, Bosnia and Herzegovina \\ 2Oneida-Herkimer-Madison BOCES, 4747 Middle Settlement Rd., New Hartford, NY, 13413, USA \\ ${ }^{3}$ Faculty of Political Science, University of Sarajevo, Skenderija 72, 71000 Sarajevo, Bosnia and Herzegovina \\ ${ }^{4}$ Faculty of Political Science, University of Sarajevo, Skenderija 72, 71000 Sarajevo, Bosnia and Herzegovina \\ ${ }^{5}$ Faculty of Political Science, University of Sarajevo, Skenderija 72, 71000 Sarajevo, Bosnia and Herzegovina \\ Correspondence: Sandro Sehic, Oneida-Herkimer-Madison BOCES, 4747 Middle Settlement Rd., New Hartford, NY, \\ 13413, USA.
}

Received: January 28, 2021

Accepted: March 14, 2021

Online Published: March 15, 2021

doi:10.11114/ijce.v4i1.5190

URL: https://doi.org/10.11114/ijce.v4i1.5190

\begin{abstract}
Education is a process that happens at both the individual level of each human being and the global level of total humanity, which never ceases to participate in the educational process. Education is a social and historical category; no society has failed to have an educational system. Helmuth von Hentig outlines this in his text and, he reminds us that education is action, process and result. The paradigm shift brought about by the accelerated transformation of society also applies to the concept of education. New technologies and the irreversible digitalization of society have already greatly influenced educational practices and processes.
\end{abstract}

Keywords: education, learning society, knowledge society, semi-education

\section{Introduction}

Helmuth von Hentig opens his famous essay, "What is Education?" with a serious question: what educates a human? He gives his answer without hesitation: as he himself says, without hesitation: everything (2008, p. 15). The importance of education is not in question, no society has given it up, and it has its own history. Hentig, the author of a large number of works, which many consider a kind of manifesto for the field of education, asks a few more important questions: - What kind of education do we want? - What kind of education should it be? This series of questions brings us to acknowledge the complexity of upbringing and education. In the history of mankind, various forms of human action and activities have appeared that are recognized as learning, cognition, or education. A man, at the beginning and before any technology was created by him, had only his mind-endowed body, or more precisely, a man had nothing, but his body bestoved, gifted by a mind. Thus, they had "an original, universal tool, more important and valuable than any later combination of tools - his mind-driven body" (Mumford, 1986, p. 8). When, as we said at the beginning, Hentig answers the question - What educates a man? - he answers everything, which indicates all of the experiences that enter a person's psychological world. This captures a human's into history of being and existence, just as every society is always learning (a "learning society") and changing with the introduction of new knowledge. The Life itself has potentially educational nature, bringing us into countless situations of new experiences. The mosaic of experiences that we have in the spectrum of relationships and encounter of and interaction with others is always within a certain social structure (Sofradžija \& Turnšek, 2021); more broadly, humans are always confronted with their destiny: the world. The world is the topos of all human happenings and existence. In simple ancient societies, knowledge, skills and techniques were transmitted through the framework of everyday life. Human beings explored, hunted, survived, observed and listened, learned about the world, long before school teaching became an obligation built into the system - the educational system. The process of discovering and transforming oneself, the art of establishing order and repeating actions, is the topic to which Mumford refers in the title The Original Art of Order (Mumford, 1986). In accordance with this, sociologists, psychologists and anthropologists point out that fear and curiosity are two important instincts of human life (Kuvačić, 1989; Sofradžija, 2004). The first instinct, fear, is manifested in the desire for stability, security, and the second, curiosity, in the desire for new experiences. Ivan Kuvačić, one of the most famous sociologists, points out that this situation is manifested at the level of social control, i.e., education, which takes place in the form of a 
duality of two opposite tendencies: one being the aspiration to stifle any new attitude that is not in line with existing social organization, and the second aimed at the destruction of the existing order and the conquest of the new (Kuvačić, 2007). If we consider a developing society, we will see that there are whole stages in which routine activity/action dominates, and there are others that are filled with creative change. According to Max Weber, the polarity between will and reason, or more clearly, between will and routine, is the inner driving force of history.

Education is a social and historical category. At the beginning of this text, we said that the importance and value of education is not in question because no society has given up on education. Education is a process of transformation; it is the enrichment of the human being with knowledge and skills, and as such, education is closely related conceptually to upbringing. Upbringing and education are essential elements and powerful, irreplaceable levers in the development of society, as such it has its own history. It is not our intention here to deal with the history of education and upbringing and various concepts from ancient human communities, in Hellas, Spartan communities in the Roman Empire, the emergence of the first schools and universities, through the Enlightenment and the famous teachings of Jean Jacques Rousseau. The Enlightenment ideal of education is known, as well as that of the modern idea of the university, which originated and developed under the influence of Enlightenment ideas. In the essay "What is the Enlightenment?" (Was ist Aufklärung? 1783), the German philosopher Immanuel Kant says: Enlightenment is one's coming out of immaturity, and immaturity is above all one's inability and unwillingness to use one's reason independently. Following in the footsteps of this essay by Kant, two hundred years later, Foucault published a text of the same title (What is the Enlightenment, 1984) in which he gives an understanding of the Enlightenment and a critique of modernity. Should it be mentioned that it was Foucault who, in his much-quoted and well-known work "Supervision and Punishment" (1994) suggested that one should renounce an entire tradition and the belief that knowledge can exist only where power relations are abolished. According to Foucault, there is no power relation without the correlative establishment of a field of knowledge or knowledge that does not establish a relationship of power - knowledge follows and amplifies the action and effects of power (Foucault, 1994, p. 29), but this is an extensive and separate topic. If we go back to the author from the very beginning of our text - when, therefore, Hentig claims that "EVERYTHING educates man" (he will mention this statement several times in the same essay) he deals with the verb "educate," which he says means to shape or leave an imprint (Hentig, 2008, p. 17). Then education is an action, "for man is a wondrous and disgusting plastic being" subject to influences; unlike other creatures, humans are capable of taking on almost limitless shape (Hentig, 2008, p. 12).

\section{Education as a Process}

Education is a process that happens both at the individual level of each human being and at the global level of total humanity, which has always been and never ceases to be in the process of education. Education is considered to be the formation of potentials: intellectual, psychological, moral, physical, aesthetic, cognitive and active possibilities. In the process of acquiring knowledge and skills, socialization has its place, as does the development of institutional education in schools. Pedagogy is considered to be a science of education that explores education as a phenomenon and concept. There is a whole range of disciplines that make up pedagogy, from docimology to didactics (Greek $\delta 1 \delta \alpha \varkappa \tau 1 x \eta \dot{~} \tau \dot{\varepsilon} \chi v \eta$ teaching skills). Helmuth von Hentig, who is also an educator, made valuable contributions to the field of didactics, school reform and humanization of the school as a whole, and he pointed out the contradictions between theory and practice. This is especially evident in his work "The Humane School - a school thought in a new way" (1997), where it asks the questions that need to be asked because the time has come to ask them. His discussion on the "feeling of happiness" as a measure of "true education" connects to and recalls the idea of original happiness, eudaimonia (Greek

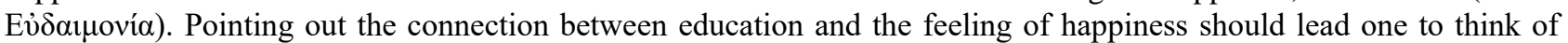
striving for an education that is worth its purpose, meaning and existence. Thus, education is a process that should yield results worth the effort, because happiness would accompany true education. The school is a place where one lives; it must not be a poorly maintained place in which everything is reduced to listening and does not involve active participation and cognition. A humane school should nurture curiosity about the world and life. Hentig attempts to describe an educated human or, at least to present the ideal-type of one - "Who is an educated man?" as an answer, he cites Robert Spaermann's of an educated individual (Hentig, 2008, pp. 17-18): - Educated people have left behind animal egocentrism, they are interested in "how the world looks in other people's eyes"; their sense of self-worth can be strong and clear "because it does not draw him from comparison with others"; it is foreign to him to give an opportunity to get to know; it is foreign to him to get rich - he is not afraid to value himself; - he often speaks scientific language, but it does not enslave him. Hentig explains that these characteristics (just to list few) are not acquired by themselves; they pass from the cultivated environment to the educated person (Hentig, 2008, p. 19). Hentig does not hesitate to go the hard way, pointing out possible contradictions. We are forced, like the ancient Greeks, to ask questions: What is a good life? What is a good man? What is a good community? In the modern studies of pedagogy and sociology, it is unavoidable to study the Hentig (1997) Humane School, along with other alternative schools: Montessori, Waldorf, 
Helen Doron and others. The Sociology of education is a sociological discipline that studies the social conditioning of education and how education affects society and culture; therefore, it explores the social, cultural and psychological aspects and context of education (Bakić, 2014).Other names are used for this discipline, including pedagogical sociology, which explores a set of methods, theories and knowledge where the application of the sociological method to pedagogical issues is clear (Sociological Lexicon, 1982, p. 652). The sociological approach to the study of the values of upbringing and education tries to answer the key questions: - who are the bearers of cultural and social values in the community?, who are the bearers of education in society? how is the content and quality of knowledge transferred?. For centuries, education was available only to a small number of people, as Anthony Giddens describes in his sociological framework; only the processes of industrialization and modernization have influenced the development of the educational system (Giddens, 2003, p. 496). Giddens (2003) devotes an entire chapter to education, touching on a number of factors from the aforementioned process of industrialization that have brought major changes to education through the privatization of education and new communication technologies in the classroom; It considers how education has changed as a result of new processes, e-universities and education crisis. He points to the importance of gender, gender differences and education, ethnicity and education, and he provides a short presentation of some theories and authors that deal with these issues (Bernstin, Illich, Burdieu, Villis..). It is obvious that the topic and problem of education is a wide and complex field. Each of the issues mentioned above is "deep water" in which to dive. In any case, we can agree with Hentig's statement that education is a process and a result.

\section{Globalization, Education and New Technologies}

Globalization is the most pronounced process of our time, and it transforms all aspects of society. The changed content of the world, which is noticeable at all levels of human experience, poses new challenges in the field of education as well. The paradigm shift brought about by the accelerated transformation of society also impacts to the concept of education; - some analysts believe that this is a marked change in the larger society's "philosophy of life" (Žiga, 2012). Advances in new information communication technology are changing the way we communicate, meet, live, perceive the world, and learn. Anthony Giddens concludes that new technologies have already greatly influenced educational processes. Namely, technology is already in the classrooms, there is talk of a "classroom revolution" and the irreversible entry of virtual reality into classrooms without walls (Giddens, 2003). Of course, as a reminder, McLuhan said the media was a "prison without walls." We all live in a hypermedia society (Sehic \& Sofradzija, 2020), where the most recognizable medium is technology. It is technology that has enabled the existence of electronic universities, distance learning, the mediation of knowledge transfer, and the lost immediacy of meeting in the classroom, which was recently written about by the Italian author Giorgio Agamben. The introduction of the online platform erases the experience of immediacy of lecturers and students, and this is a university experience that lasted for almost ten centuries; now, according to Agamben (2020), it is fading away forever. Agamben (2020) indicates a farewell to an idea of education that carried the essential values of encounter, dialogue and direct interaction. Virtual classrooms and encounters in interspace cannot replace encounters in real classrooms. The comprehensive diffusion of digital technologies has led to the consequent transformation of education and knowledge transfer. Does this change the quality of knowledge? Does it still remain the knowledge for which Bacon's famous saying - scientia est potentia - is valid? He understands knowledge as one of the greatest values of any society. So, an important dimension of the educational system is the transfer of knowledge. We live in a "Knowledge Society," and this phrase has a number of different interpretations. The meaning of; this or the concept of a "global knowledge society," can be discussed in another text; that is not our intention here, because analysis and dealing with the topic would require a special space. The whole construction of the world today is essentially scientific-technical (according to Lyotard, scientific knowledge is not all knowledge: often knowledge is reduced only to scientific knowledge). Jean-François Lyotard in the introduction to Postmodern State states that the subject of his study is the state of knowledge in postmodern society (Lyotard, 1979). After Gutenberg's galaxy, humanity entered McLuhan's galaxy, which moves away from the written word and enters a "culture of images" where it agrees Life on the Screen. It is a culture in which the manuscript has disappeared and, been replaced by the keyboard - (H. G. Gadamer: where did the manuscript of modern man disappear?). In "Narcissistic Culture" (subtitled "Education as a Commodity"), Christopher Lasch argues that the crisis of education is evident and that education, in a specific way, becomes a commodity that is traded as would be any other commodity (Lasch, 1986, p. 171). This is a warning about the commercialization of education, which is considered detrimental to the quality and content of education. Likewise, a number of authors talk about the banalization of knowledge and the education industry (Liessmann, 2008; Lavić, 2018). These thinkers use terms such as "knowledge management", "knowledge balance", "knowledge economization" to signal that knowledge is not respected in the "knowledge society" (Liesmann, 2008). The rise of a networked society brings new understandings of knowledge and new practices, as well as new system of organization and structure, but there is always talk of education for the future. 


\section{Education, Semi-Education, Ignorance}

In Konrad Liessmann's book The Theory of Ignorance - Misconceptions of the Knowledge Society (2008), one chapter carries the subtitle - "Education, semi-education, ignorance." Following Theodor Adorno's essay, "The Theory of Half Education" (1959) in which he analyzes the state of education, Liessmann (2008) wrote The Theory of Ignorance. Namely, Adorno was of the opinion that if humanistic education becomes a goal for those people who lack the prerequisites for it, the consequence is that semi-education appears. Semi-education is a misunderstanding, tied to the category of education; it is in fact education's degradation. According to Liessmann (2008) he traces and elements of semi-education understood and recognized by Adorno (1959) are visible everywhere today. Ignorance today is not an intellectual deficit, it is not a lack of information, it is not a defect of cognitive competence, but it is rather a renunciation of the desire to understand something at all - Liessmann (2008) explains - "Ignorance" means that the idea of education has ceased to fulfill a normative or regulatory function. Education is increasingly aligned with elements such as the market and technological development that are set as the standards that an "educated" person must achieve, which on this account is the "absence of education" (Liessmann, 2008). Lavić (2008) points out that "semi-education does not understand the importance of educated people in society, skill has replaced knowledge" (p. 188). This is thought to happen at a time when the boundaries between truth and lies cease to be clear, at a time dominated by fake news, when ignoring knowledge and essential social values are ignored. The author of the Introduction to Continuing Education, Paul Langran (1976), draws attention to this crisis of life patterns and relationships, the everywhere noticeable crisis of social values. The greatest value is given and attributed to "technical, administrative knowledge," according to Apple (2019), because the possession of such knowledge enables one to come to positions of power and influence; it is the type of knowledge that is applied in running large corporations in a competitive global economy. Where knowledge is lost in information, then - information is turned into knowledge placed in the wider context of society. Search engines in the digital ocean increasingly provide information and fragmented knowledge that according to many modern authors, it could paradoxically, hinder the acquisition of knowledge because everything is so delivered to the requirements of dromology and fragment, or fracture. Such fragmented knowledge lacks the power of synthesis and is a fragment that is easily adopted, quickly adapted and easily forgotten. This is exactly what Liessmann (2008) is talking about: knowledge even becomes part of the entertainment industry. One example he cites is the quiz show Who Wants to Be a Millionaire. Formats like this television show, a chain of licensed shows all over the world, indicate the state of education at the level of mass media entertainment: which is ultimately a form of ignorance. Finally, Liessmann (2008) points out that education is - so to speak - a requirement for appropriate understanding. It should be said that modern media promote semi-education, as indicated by a large number of theorists from the fields of education, mediology, psychology, communication, sociology, and many other scientific fields. The media are increasingly taking on the role that school and family used to have, and entire scientific studies deal with this phenomenon. How we are shaped by modern technology, media and the mediation of society (Delic et al, 2020) is becoming an increasingly important question, and whether it seems more recognizable that in such circumstances in a specific way more and more "journalistic" approach to knowledge. There has never been a lack of reformers in education, the question and challenge remain to what extent the processes of education will continue to be influenced by the historical transformations of the larger society. Finally, after all of these open questions, we add one more: what will be the future of education?

\section{Conclusion}

Education is a social and historical category, as we said earlier in the text, and precisely because education is an indispensable resource for all societies, it deserves great attention. A large number of questions are opened in this text-essay because the questions themselves are guidelines for reflection. The statement that education is an action, $a$ process and a result in itself points to the complexity of this issue. Since education is the enrichment of knowledge, skills, art, cognition, and understanding, education is then an attempt at encouraging a desired transformation towards a better society. The concept of education is changing in many ways for a variety of reasons, and here we have spoken about and pointed to the historical transformation of society that leads to the shift of essential social paradigms. New technologies have unquestionably and evidently influenced educational processes: technology has been in classrooms for a long time, which has impacted the mediation of knowledge transfer, distance learning and, the lost immediacy of encounters in the classroom. There is no doubt that the pandemic has given / created a new social reality, which greatly changes human action on all levels, as well as in the field of education in particular. It has come to rely even more on the use of technology. As we said before, the comprehensive diffusion of innovative technologies and the irreversible digitalization of society has led to the transformation of education and the way knowledge is transferred. The research we conducted on a specific sample of students was primarily inspired by the need to understand how students see the new situation where a pandemic has brought education systems in all countries into a very specific condition. The new circumstances caused by the pandemic have introduced the challenge of adapting and finding new forms of communication between lecturer and student. Education has faced new challenges. Respondents answered a question 
that explored whether they prefer the traditional way of transferring knowledge and meeting in a real classroom or meeting in virtual classrooms where the meeting is mediated by technology. Most of the respondents answered that they prefer the traditional way of transferring knowledge in real classrooms, where the immediacy of the lecturer and the student is achieved. The increasingly common practice in educational systems to transfer knowledge and communicate across spatial distance is not, as much as has been claimed in some cases, the realization of the fullness and quality of education. In a way, this fundamentally changes and redefines the essential elements of education and upbringing. Every mediated relationship is in some way a reduced relationship, deprived of immediacy, intimacy and authentic encounter. This is supported by the answers to RQ4 in the research, namely, according to the data obtained, over $75 \%$ of respondents / students stated that personal direct interaction with the professor and other fellow students makes them happy and helps them master the material and develop an understanding of the overall process. Appended to this text will be the results of a survey conducted in December 2020 of a sample of 139 respondents. This is a pioneering contribution of this paper because academic communities are still facing the challenge of understanding the starting points and outcomes of this way of working with students.

\subsection{Quantitative Survey Research}

Different social factors and historical circumstances contributed to the changes in education. Educational changes affected curriculum plans (what learners need to learn) as well as instructional methods (how learners will be taught). The pandemic of COVID-19 is not exceptional in educational reforms and forced educational systems to adapt new teaching strategies that would allow learners to acquire new learning materials on the distance. In addition, the pandemic significantly affected learners throughout the world and forced them to adopt new learning styles that would allow them to follow the instructions from the distance. Reforms in educational systems initiated by the pandemic may not mean disadvantages to educational system nor learning in general. The effects of the new educational reforms initiated by pandemics on learning achievements and academic success in general are yet to be evaluated by the educators and social scientists as well as the effectiveness of newly adopted teaching and learning methods. It is the time to conduct research studies that would provide academic communities throughout the world with information to better understand the effects of online and distance education on the outcomes of learning and education in general.

\subsection{Purpose of the Research Study}

The purpose of this quantitative survey study was to collect data from the college students from to understand how new educational and instructional changes affected their educational process and transition to online/distance education. The literature review did not reveal research studies that explained educational process and results in the era of pandemic with sociological approach. The current study will address the gap and provide information that will benefit educators and sociologists to better understand educational process and online/distance education during the pandemic.

\subsection{Research Questions and Hypotheses}

The literature review did not reveal research studies that would provide educational community with information about online/distance education during the pandemic that would serve educational community to improve educational practices and increase students' achievement. Therefore, this quantitative survey study aimed to answer the following research questions:

RQ1: Do college students prefer traditional classroom-based instructions or online/distance instructions?

H01: College students do not have significantly prefer one type of instructions over the other.

HA1: College students do significantly prefer one type of instructions over the other.

RQ2: What characteristics do college students value most at their college professors and instructors?

H02: College students do not specifically value a certain characteristic of a college professor or instructor.

HA2: College students do not specifically value a certain characteristic of a college professor or instructor.

RQ3: What type of instructions, traditional classroom-based instructions or online/distance instructions, help college students learn best?

H03: Traditional classroom-based instruction and online/distance instructions equally help college students to learn.

HA3: Traditional classroom-based instruction and online/distance instructions equally help college students to learn.

The hypotheses were not set for the open-ended questions:

RQ4: What factors contribute to learning process and happiness of the college students?

RQ5: What factors can facilitate learning process and happiness among college students?

RQ6: What does education mean to college students? 


\section{Methodology}

\subsection{Data collection}

The data in this quantitative survey research study were collected by a questioner that included three multiple-choice questions and three open-ended questions through SurveyMonkey in December of 2020.

\subsection{Population}

The population in this quantitative survey study consists of approximately 250.7 million $(n=250.7$ million) college-level students in the world as of 2020 as predicted by UNESCO (ICEF Monitor, 2020).

\subsection{Sample size}

The research study included total of 139 college-level learners $(\mathrm{N}=139)$ that were registered with SurveyMonkey platform and who voluntarily decided to participate in the research study.

\subsection{Materials/Instruments}

Electronic version of a questionnaire with three multiple-choice questions and three-open ended questions was used to collect the data in this quantitative survey study.

\subsection{Data analysis}

The collected data from the multiple-choice questions was analyzed by SPSS online software. One-way chi-square test was used to analyze collected data and test the null hypotheses. The statistical difference (Sig.) between the survey results from both groups was used to answer research questions and to determine whether to retain or reject the null hypotheses. A p-value of less or equal than $5 \%(\mathrm{p} \leq 0.05)$ indicated that the test is statistically significant and the null hypotheses was rejected, whereas the null hypotheses was retained for every research question where the p-value proved to be greater than $5 \%(\mathrm{p}>0.05)$. The collected data from the open-ended questions was reviewed and discussed separately from the data collected by the multiple-choice questions.

\section{Results for the Research Questions}

RQ1: Do college students prefer traditional classroom-based instructions or online/distance instructions?

Table 1.

\begin{tabular}{lll}
\hline Traditional classroom-based instructions & 87 & $63 \%$ \\
Online/distance instructions & 52 & $37 \%$ \\
\hline
\end{tabular}

Note: The first numerical column indicates the number of participants.

Table 2.

\begin{tabular}{llll}
\hline & Value & df & Asymptotic Significance (1-sided) \\
\hline Pearson chi-square & 8.813 & 1 & 0.003 \\
\hline
\end{tabular}

Note: Asymptotic Significance $(1-$ sided $)=p$

As indicated in Table 2, a statistically significant difference between instructional preferences among college students who participated in this research study was found $\chi^{2}(1, \mathrm{~N}=139)=0.003, \mathrm{p}<0.05$. Therefore, the null hypothesis was not accepted, the alternative hypothesis was not rejected. The findings suggest that college students who participated in this research study favor traditional classroom-based instructions over online-distance instructions. 
RQ2: What characteristics do college students value most at their college professors and instructors?

Table 3.

\begin{tabular}{lll}
\hline Expertise in the academic area & 47 & $34 \%$ \\
Tutoring availability & 16 & $12 \%$ \\
Willingness to assist students & 41 & $29 \%$ \\
Friendly relationship with students & 21 & $15 \%$ \\
Community involvement & 3 & $2 \%$ \\
Similar life experience & 4 & $3 \%$ \\
Other & 7 & $5 \%$ \\
\hline
\end{tabular}

Note: The first numerical column indicates the number of participants.

Table 4.

\begin{tabular}{llll}
\hline & Value & df & Asymptotic Significance (1-sided) \\
\hline Pearson chi-square & 95.727 & 6 & 0.001 \\
\hline
\end{tabular}

Note: Asymptotic Significance (1-sided) $=p$

As indicated in Table 4, a statistically significant difference between characteristics preferences of college professors and instructors among college students who participated in this research study was found $\chi^{2}(6, \mathrm{~N}=139)=0.001, \mathrm{p}<$ 0.05. Therefore, the null hypothesis was not accepted, the alternative hypothesis was not rejected. The findings suggest that college students who participated in this research study have preferences for certain characteristics of college professors and instructors.

RQ3: What type of instructions, traditional classroom-based instructions or online/distance instructions, help college students learn best?

Table 5.

\begin{tabular}{lll}
\hline Traditional classroom-based instructions & 98 & $70 \%$ \\
Online/distance instructions & 41 & $30 \%$ \\
\hline
\end{tabular}

Note: The first numerical column indicates the number of participants.

Table 6.

\begin{tabular}{llll}
\hline & Value & df & Asymptotic Significance (1-sided)___ \\
\hline Pearson chi-square & 23.374 & 1 & 0.001 \\
\hline
\end{tabular}

Note: Asymptotic Significance (1-sided) $=p$

As indicated in Table 6, a statistically significant difference between the type of instructions that help college students in the United States who participated in this research study learn best was found $\chi^{2}(1, \mathrm{~N}=139)=0.001, \mathrm{p}<0.05$. Therefore, the null hypothesis was not accepted, the alternative hypothesis was not rejected. The findings suggest that college students who participated in this research study learn better when instructed with traditional classroom-based instructions.

RQ4: What factors contribute to learning process and happiness of the college students?

The answers to RQ4 were divided into three main categories in order to better understand participants responses. Over $75 \%$ of participants stated that personal interaction with the professor and other students makes them happy and helps them to learn. Based on the information received from RQ4, it could be concluded that college students prefer traditional classroom-based instructions that gives them opportunity to directly communicate with the professor and the classmates.

RQ5: What factors can facilitate learning process and happiness among college students?

The answers to RQ5 were divided into three main categories. Participants in the research study that the following 
factors facilitate learning and happiness for college students: a) Effective instructions that will help them understand the lesson; b) classmates and the relationships with classmates; c) qualified instructors and their willingness to assist students.

RQ6: What does education mean to college students?

The answers from RQ6 suggest that participants in this research study see education as a) an opportunity to gain new skills and knowledge that will help them succeed in life and b) a change that affects their thinking and reasoning skills. These findings relate to the definition of learning from psychological perspective that learning is permanent change in behavior and thinking brought upon by experience. Knowledge is power (scientia est potentia), knowledge is a way to embrace the world, to know, to comprehend, to understand. There has never been a lack of reformers in education, the question and challenge remain as to how the processes of education will continue to change and move in this period of historical transformation.

\section{Conclusion for the Quantitative Survey}

The results of this quantitative survey provided significant answers that can further contribute to the educational administrators and the college instructors. According to the results: a) College students prefer traditional classroom-based instructions $(63 \%)$ over online/distance instructions $(37 \%)$; b) College students are primarily interested in learning from instructor who are experts in the academic area they teach (34\%) followed by their willingness to assist their students $(29 \%)$ and their friendly relationship with students (15\%); c) College students state that traditional classroom-based instructions help them learn better (70\%) than online/distance (30\%); d) Over $75 \%$ of participants stated that personal interaction with the professor and other students makes them happy and helps them to learn; e) College students who participated in this survey stated that the factors that facilitate their learning and happiness are effective instructions, relationships with the classmates, and qualified instructors who are willing to assist their students; and f) College students who participated in this survey stated that they see education as an opportunity to gain new knowledge and skills and to change their way of thinking and reasoning skills. The results of the survey provide information that can further serve educators to write curriculum and plan instructional design that will increase students' academic achievement. In addition, the results of the survey can further serve academic community to build and organize future research studies to further explore educational process.

\section{References}

Adorno, T. W. (1959). Theorie der Halbbildung [Theory of Half Education] In: Adorno, T. (1998): Gesammelte Schriften [Collected writings]. Darmstadt: Wissenschaftliche Buchgesellschaft, p. 93-121.

Agamben, G. (2020). Rekvijem za student [Requiem for students]. Pescanik. Retrieved from https://pescanik.net/rekvijem-za-studente

Alibegović, A., \& Čaušević, M. (2016). Društvo 21. stoljeća-ključna obilježja i problemi [21 ${ }^{\text {st }}$ Century Society - Key Features and Issues], DHS Društvene i humanističke studije 1, Filozofski fakultet Tuzla, 151-163. Retrieved from http://oaji.net/articles/2020/8977-1602847641.pdf

Apple, M. W. (2019). Ideology and Curriculum (4 ${ }^{\text {th }}$ ed.). Routledge, NY: Psychology Press.

Bakić, S. (2014). Ključni aspekti sociologije obrazovanja [The key aspects of sociology of education]. Casopis Obrazovanja Odraslih [Journal of Adult Education and Culture], 374.7, 112-124. Retrieved from https://www.dvv-international.ba/fileadmin/files/bosnia-and-herzegovina/

Delic, A. et al (2020). Razumijevanje interneta: Kako oblikujemo novi medij i kako on oblikuje nas [Understanding internet: How we shape the new media and how it shapes us]. DHS, Društvene i humanističke studije, 2(11), 299-316. Retrieved from http://oaji.net/articles/2020/8977-160164

Foucault, M. (1984). Šta je prosvjetiteljstvo [What is Enlightenment?]. Retrieved from https://www.6yka.com/novosti/michel-foucault-sta-je-prosvjetiteljstvo

Giddens, A. (2003). Sociologija [Sociology]. Ekonomski fakultet, Beograd.

Hentig, H. (1997). Humana škola - škola mišljena na nov način [Humane school - school thought in a new way]. Zagreb, Croatia: Educa.

Hentig, H. (2008). Šta je obrazovanje [What is education?]. Zagreb, Croatia: Educa.

ICF Monitor. (2021, March 8). Study projects dramatic growth for global higher education through 2042. Retrieved from

https://monitor.icef.com/2018/10/study-projects-dramatic-growth-global-higher-education2040/\#: :text=A\%20new ly\%20updated $\% 20$ study $\% 20$ maps, in $\% 20$ universities $\% 20$ around $\% 20$ the $\% 20$ world. 
Kuvačić, I. (1989). Sociologija - uvođenje u raspravu o aktualnim pitanjima suvremenog društva [Sociology introduction to dialog about contemporary issues of modern society]. Zagreb, Suvremena misao.

Kuvačić, I. (2007). O rutinizaciji života [On routinization of life]. Retrieved from https://www.marxists.org/srpshrva/biblioteka/kuvacic

Langran, P. (1976). Uvod u permanentno obrazovanje [An introduction to lifelong learning]. Beograd

Lash, Ch. (1986). Narcistička kultura [Narcistic culture]. Zagreb: Naprijed.

Lavić, S. (2018). Zaborav razlike - Bosanski prekarijat, ,, bolonjski” univerzitet i medijski cinizam. Sarajevo, Dobra knjiga.

Liessmann, K. P. (2008). Theorija neobrazovanosti, zablude drustva znanja [Theorie der Unbildung, Die Irrtümer de Wissensgesellschaft]. Zagreb, Croatia: Naklada Jesenski Turk.

Lyotard, J. F. (1979). La condition postmoderne [The Postmodern condition]. Paris, France: Les Éditions de Minuit.

Mumford, L. (1986). Mit o mašini, GZH, Zagreb [The myth of the machine: Technics and human development]. (Volume 1). New York, NY

Sehic, S., \& Sofradzija, H. (2020). Media and the phenomenon of spectacle. International Journal of Information Research and Review, 7(10), 7106-7108. Retrieved from http://www.ijirr.com/sites/default/files/issues-pdf/3686.pdf

Socioloski leksikon (1982). [Sociological lexicon]. Belgrade: Savremena administracija.

Sofradžija, H. (2004). Strah kao psihološka kategorija [Fear as a psychological cathegory]. Naša škola, časopis za teoriju i praksu odgoja i obrazovanja, Sarajevo, 27, 135-148. Retrieved from http://www.nasaskola.ba/portfolio/sofradzija-halima/

Sofradzija, H., \& Adzajlic-Dedovic, A. (2013). Nelagodnost u procesu globalizacije. Evropski univerzitet, Skopje, Macedonia, 144-152. Retrieved from https://core.ac.uk/download/pdf/35330753.pdf

Sofradžija, H., \& Turnšek, M. (2021). Social interaction and the experience of the other. Drustvene I humanisticke studije, 6, 1(14), 409-418. https://doi.org/10.51558/2490-3647.2021.6.1.409

Žiga, J. (2012). Vrijeme (sve) politike - iluzije savremenog ekologizma [Time of (all) politics - illusions of modern ekoglism]. Sarajevo. Dobra knjiga.

\section{Copyrights}

Copyright for this article is retained by the author(s), with first publication rights granted to the journal.

This is an open-access article distributed under the terms and conditions of the Creative Commons Attribution license which permits unrestricted use, distribution, and reproduction in any medium, provided the original work is properly cited. 